Article

\title{
Development and Validation of a Chiral Liquid Chromatographic Assay for Enantiomeric Separation and Quantification of Verapamil in Rat Plasma: Stereoselective Pharmacokinetic Application
}

\author{
Mostafa S. Mohammed ${ }^{1,2} \mathbb{D}$, Mohamed M. Hefnawy ${ }^{1,3, * \mathbb{D}}$, Abdulrhman A. Al-Majed ${ }^{1}$, Haitham K. Alrabiah ${ }^{1}$, \\ Nasser A. Algrain ${ }^{1}$, Ahmad J. Obaidullah ${ }^{1} \mathbb{D}$, Abdulmalik S. Altamimi ${ }^{4}$, Yousef A. Bin Jardan ${ }^{5}$ \\ and Abdullah M. Al-Hossaini ${ }^{1}$ \\ Citation: Mohammed, M.S.; \\ Hefnawy, M.M.; Al-Majed, A.A.; \\ Alrabiah, H.K.; Algrain, N.A.; \\ Obaidullah, A.J.; Altamimi, A.S.; Bin \\ Jardan, Y.A.; Al-Hossaini, A.M. \\ Development and Validation of a \\ 1 Department of Pharmaceutical Chemistry, College of Pharmacy, King Saud University, P.O. Box 2457, \\ Riyadh 11451, Saudi Arabia; mostafanodcar@yahoo.com (M.S.M.); almajed99@yahoo.com (A.A.A.-M.); \\ halrabiah@ksu.edu.sa (H.K.A.); n_algrain@hotmail.com (N.A.A.); aobaidullah@ksu.edu.sa (A.J.O.); \\ abalhossaini@ksu.edu.sa (A.M.A.-H.) \\ 2 National Organization for Drug Control and Research, Cairo P.O. Box 29, Egypt \\ 3 Department of Analytical Chemistry, Faculty of Pharmacy, Mansoura University, Mansoura 35516, Egypt \\ 4 Department of Pharmaceutical Chemistry, College of Pharmacy, Prince Sattam Bin Abdulaziz University, \\ Al-Kharj 11942, Saudi Arabia; as.altamimi@psau.edu.sa \\ 5 Department of Pharmaceutics, College of Pharmacy, King Saud University, P.O. Box 2457, \\ Riyadh 11451, Saudi Arabia; ybinjardan@ksu.edu.sa \\ * Correspondence: mhefnawy@ksu.edu.sa; Tel.: +966-1-467-7346; Fax: +966-1-467-6220
} Chiral Liquid Chromatographic Assay for Enantiomeric Separation and Quantification of Verapamil in Rat Plasma: Stereoselective Pharmacokinetic Application. Molecules 2021, 26, 2091. https://doi.org/10.3390/ molecules26072091

Academic Editors: Rudy

J. Richardson, Nicola Marchetti and Anna Laura Capriotti

Received: 28 February 2021

Accepted: 4 April 2021

Published: 6 April 2021

Publisher's Note: MDPI stays neutral with regard to jurisdictional claims in published maps and institutional affiliations.

Copyright: (C) 2021 by the authors Licensee MDPI, Basel, Switzerland. This article is an open access article distributed under the terms and conditions of the Creative Commons Attribution (CC BY) license (https:// creativecommons.org/licenses/by/ $4.0 /)$.

\begin{abstract}
A novel, fast and sensitive enantioselective HPLC assay with a new core-shell isopropyl carbamate cyclofructan 6 (superficially porous particle, SPP) chiral column (LarihcShell-P, LSP) was developed and validated for the enantiomeric separation and quantification of verapamil (VER) in rat plasma. The polar organic mobile phase composed of acetonitrile/methanol/trifluoroacetic acid/triethylamine (98:2:0.05: 0.025, $v / v / v / v)$ and a flow rate of $0.5 \mathrm{~mL} / \mathrm{min}$ was applied. Fluorescence detection set at excitation/emission wavelengths $280 / 313 \mathrm{~nm}$ was used and the whole analysis process was within $3.5 \mathrm{~min}$, which is 10-fold lower than the previous reported HPLC methods in the literature. Propranolol was selected as the internal standard. The S-(-)- and R-(+)-VER enantiomers with the IS were extracted from rat plasma by utilizing Waters Oasis HLB C18 solid phase extraction cartridges without interference from endogenous compounds. The developed assay was validated following the US-FDA guidelines over the concentration range of $1-450 \mathrm{ng} / \mathrm{mL}\left(\mathrm{r}^{2} \geq 0.997\right)$ for each enantiomer (plasma) and the lower limit of quantification was $1 \mathrm{ng} / \mathrm{mL}$ for both isomers. The intraand inter-day precisions were not more than $11.6 \%$ and the recoveries of S-(-)- and R-(+)-VER at all quality control levels ranged from $92.3 \%$ to $98.2 \%$. The developed approach was successfully applied to the stereoselective pharmacokinetic study of VER enantiomers after oral administration of $10 \mathrm{mg} / \mathrm{kg}$ racemic VER to Wistar rats. It was found that S-(-)-VER established higher $\mathrm{C}_{\max }$ and area under the concentration-time curve (AUC) values than the R-(+)-enantiomer. The newly developed approach is the first chiral HPLC for the enantiomeric separation and quantification of verapamil utilizing a core-shell isopropyl carbamate cyclofructan 6 chiral column in rat plasma within $3.5 \mathrm{~min}$ after solid phase extraction (SPE).
\end{abstract}

Keywords: verapamil enantiomers; core-shell chiral column; chiral HPLC; rat plasma; stereoselective pharmacokinetics

\section{Introduction}

Fast and efficient separation of a wide range of drugs is a challenge in HPLC. Fast separation results in high operating pressure, which places a massive load on HPLC 
instrumentation [1]. Furthermore, higher selectivity and sensitivity are advantages of using UHPLC in analytical chromatography [2]. Unfortunately, the use of UHPLC is counteracted by some of its limitations such as low peak area repeatability values due to the small injection volumes, high difficulty in packing of the tiny sub- $2 \mu \mathrm{m}$ particle columns, and the short column lifetime, which may be attributed to the high back pressure $[3,4]$. In recent years, core-shell silica particles stationary phases (solid core and porous shell) have been used as an alternative technology to overcome these disadvantages due to the highly efficient separation with a fast flow rate and reasonably low back pressure [5]. The porous shell and small solid core can afford a higher surface area for the separation to occur while the solid core plus the porous shell gives a larger particle and thus low operating back pressure [5]. Studies comparing the conventional totally porous particles and coreshell particles have been done to determine different drug groups [6-10]. There are few studies on the application of core-shell silica materials in chiral chromatography [11-13]. Recently, isopropyl cyclofructan-6 bonded superficially porous particles (SPPs) were shown to afford higher efficiency and faster separations for pharmaceutical, biological and forensic samples [14,15].

Verapamil (VER, 2-(3,4-dimethoxyphenyl)-5-[2-(3,4-dimethoxyphenyl)ethyl-methylam ino]-2-propan-2-yl-pentanenitrile, Figure 1), is a phenylalkylamine calcium channel blocking drug used in the treatment of heart arrhythmias, high blood pressure and angina. VER was the first calcium channel antagonist to be introduced into therapy, and works by relaxing the muscles of the heart and blood vessels [16]. VER is obtainable as a racemate (rac-VER) that contains equal amounts of S-(-)- and R-(+)-isomer. The two isomers are readily distinguished by biological systems, they have different pharmacokinetic behavior, pharmacodynamics and/or toxicological effects [17]. In previous studies conducted in humans, the S-(-)-enantiomer carries approximately 20 -fold greater potency than the $\mathrm{R}-(+)$-enantiomer in slowing cardiac conduction velocity [18]. Moreover, in contrast to human plasma, the effect of S-(-)- and R-(+)-enantiomers of VER on rat plasma was different in vivo [19]. The toxic level of VER is observed at concentrations of more than $1000 \mathrm{ng} / \mathrm{mL}$, while the therapeutic plasma concentration of the drug ranged from 20 to $500 \mathrm{ng} / \mathrm{mL}$ [20]. Therefore, a therapeutic drug monitoring (TDM) study is essential due to its narrow therapeutic index [21]. Moreover, enantiomeric analysis of racemic drugs should be considered to both maximize the efficacy and minimize the toxicity of drug therapy [22].<smiles>COc1ccc(CCN(C)CCC[C@](C#N)(c2ccc(OC)c(OC)c2)C(C)C)cc1OC</smiles><smiles>COc1ccc(CCN(C)CCC[C@](C#N)(c2ccc(OC)c(OC)c2)C(C)C)cc1OC</smiles>

S-(-)-Verapamil<smiles>CC(C)NCC(O)COc1cccc2ccccc12</smiles>

$\mathrm{R}-(+)$-Verapamil

Propranolol (IS)

Figure 1. Chemical structure of verapamil enantiomers and propranolol (IS).

There are several bioanalytical reported methods for chiral resolution and determination of VER using HPLC [23-36], capillary electrophoresis (CE) [37-43] and LCMS/MS [44-49]. CE methods display excellent chiral separation; however, the CE assay needs a longer run time of approximately $32 \mathrm{~min}$ for enantioseparation [40,41]. Moreover, the CE technique is not always available in clinical laboratories [50]. Although LC-MS/MS is a potential tool in determination of drugs, its high cost and instrumentation complexity limit its routine application in bioanalytical laboratories. For enantiomeric separation and 
quantification of racemic drugs, HPLC is preferred due to high inherent specificity, high accuracy and remarkable precision with low cost. However, the literature reveals that reported HPLC methods for enantioanalysis of VER use a high amount of organic solvents with a longer analysis time of approximately $34-40 \mathrm{~min}[23,30,31]$. The chiral separation HPLC bioanalytical methods of VER that have been previously reported are summarized in Table 1 . The alternative approach is the application of core-shell isopropyl carbamate cyclofructan 6 chiral stationary phase (LarihcShell-P, LSP) for highly efficient separation with reduced run times $(3.5 \mathrm{~min}$ ). This core-shell chiral column provides the same efficient separations as the sub $2 \mu \mathrm{m}$ particles that are used in UHPLC without the disadvantage (high back pressure).

Table 1. Chiral HPLC separation methods reported for verapamil determination.

\begin{tabular}{|c|c|c|c|c|c|c|c|}
\hline $\begin{array}{l}\text { Determinate } \\
\text { Method }\end{array}$ & Chiral Selector & $\begin{array}{l}\text { Composition of the } \\
\text { Mobile Phase }\end{array}$ & Matrix & $\begin{array}{l}\text { Ext. } \\
\text { Method }\end{array}$ & $\underset{\text { (min) }}{\text { Run Times }}$ & $\begin{array}{c}\text { LR } \\
\text { (ng/mL) }\end{array}$ & Ref. \\
\hline $\begin{array}{l}\text { HPLC- } \\
\text { Fluorescence }\end{array}$ & $\begin{array}{c}\text { Chiral-AGP column } \\
\left(\alpha_{1} \text {-acid glycoprotein }\right) \\
(100 \mathrm{~mm} \times 4.0 \mathrm{~mm}, 5 \mu \mathrm{m}) .\end{array}$ & $\begin{array}{l}\text { Acetonitrile: } 10 \mathrm{mM} \\
\text { sodium perchlorate, } \\
\text { pH } 7.0(10: 90, v / v)\end{array}$ & $\begin{array}{l}\text { Human } \\
\text { serum }\end{array}$ & SPE & 40 & $20-400$ & [30] \\
\hline $\begin{array}{l}\text { HPLC- } \\
\text { Fluorescence }\end{array}$ & $\begin{array}{c}\text { Chiral-AGP column } \\
\left(\alpha_{1} \text {-acid glycoprotein }\right) \\
(100 \mathrm{~mm} \times 4.0 \mathrm{~mm}, 5 \mu \mathrm{m})\end{array}$ & $\begin{array}{l}\text { Acetonitrile: } 10 \mathrm{mM} \\
\text { sodium perchlorate, } \\
\text { pH } 7.0(10: 90, v / v)\end{array}$ & $\begin{array}{l}\text { Human } \\
\text { serum }\end{array}$ & LLE & 40 & $20-400$ & [31] \\
\hline $\begin{array}{l}\text { HPLC- } \\
\text { Fluorescence }\end{array}$ & $\begin{array}{l}\text { Chiralcel OD-RH column } \\
\quad \text { cellulose tris(3,5-di- } \\
\text { methylphenylcarbamate) } \\
(150 \mathrm{~mm} \times 4.6 \mathrm{~mm}, 5 \mu \mathrm{m})\end{array}$ & $\begin{array}{c}\text { Acetonitrile: } 30 \mathrm{mM} \\
\text { hexafluorophos- } \\
\text { phate, pH } 4.6 \\
(34: 66, v / v)\end{array}$ & $\begin{array}{l}\text { Human } \\
\text { plasma }\end{array}$ & LLE & 34 & $10-250$ & [23] \\
\hline $\begin{array}{l}\text { HPLC- } \\
\text { Fluorescence }\end{array}$ & $\begin{array}{l}\text { Chiralcel OD-RH column } \\
\quad \text { cellulose tris }(3,5 \text {-di- } \\
\text { methylphenylcarbamate }) \\
(250 \mathrm{~mm} \times 4.6 \mathrm{~mm}, 10 \mu \mathrm{m})\end{array}$ & $\begin{array}{c}\text { Acetonitrile: } 0.2 \mathrm{M} \\
\text { sodium perchlorate } \\
(40: 60, v / v)\end{array}$ & Urine & SPE & 25 & $2.5-300$ & [24] \\
\hline $\begin{array}{l}\text { HPLC- } \\
\text { Fluorescence }\end{array}$ & $\begin{array}{l}\text { Chiralpak AD column } \\
\text { (amylose tris }\left(3,5-\text { di- }^{-}\right. \\
\text {methylphenylcarbamate }) \\
(250 \mathrm{~mm} \times 4.6 \mathrm{~mm}, 5 \mu \mathrm{m})\end{array}$ & $\begin{array}{c}n \text {-hexane: } \\
\text { isopropanol: } \\
\text { diethylamine } \\
(94: 6: 0.1)(v / v / v)\end{array}$ & $\begin{array}{l}\text { Rat plasma } \\
\text { and tissues }\end{array}$ & LLE & 20 & $100-500$ & [25] \\
\hline $\begin{array}{l}\text { HPLC- } \\
\text { Fluorescence }\end{array}$ & $\begin{array}{l}\text { Chiralpak AD column } \\
\text { (amylose tris }(3,5-d i- \\
\text { methylphenylcarbamate) } \\
(250 \mathrm{~mm} \times 4.6 \mathrm{~mm}, 5 \mu \mathrm{m}\end{array}$ & $\begin{array}{c}n \text {-hexane: } \\
\text { isopropanol: } \\
\text { diethylamine } \\
(90: 10: 0.1)(v / v / v)\end{array}$ & $\begin{array}{l}\text { Human } \\
\text { plasma }\end{array}$ & LLE & 20 & $50-500$ & [26] \\
\hline $\begin{array}{l}\text { HPLC- } \\
\text { Fluorescence }\end{array}$ & $\begin{array}{l}\text { Chiralpak AD column } \\
\text { (amylose tris(3,5-di- } \\
\text { methylphenylcarbamate) } \\
(250 \mathrm{~mm} \times 4.6 \mathrm{~mm}, 5 \mu \mathrm{m}\end{array}$ & $\begin{array}{c}n \text {-hexane: } \\
\text { isopropanol: } \\
\text { triethylamine } \\
(85: 15: 0.4)(v / v / v)\end{array}$ & $\begin{array}{l}\text { Human } \\
\text { plasma }\end{array}$ & LLE & 20 & $2.5-100$ & [27] \\
\hline $\begin{array}{l}\text { HPLC- } \\
\text { Fluorescence }\end{array}$ & $\begin{array}{c}\text { Chiral-AGP column } \\
\left(\alpha_{1} \text {-acid glycoprotein }\right) \\
(100 \mathrm{~mm} \times 4.0 \mathrm{~mm}, 5 \mu \mathrm{m}) .\end{array}$ & $\begin{array}{l}\text { Acetonitrile: } 30 \mathrm{mM} \\
\text { phosphate buffer, } \\
\text { pH } 5.3(4: 96, v / v)\end{array}$ & $\begin{array}{l}\text { Human } \\
\text { serum }\end{array}$ & LLE & 20 & 10-120 & [33] \\
\hline
\end{tabular}

AGP: Alpha1-acid glycoprotein; AD: amylose tris(3,5-di- methylphenylcarbamate; OD-RH: cellulose tris(3,5-di- methylphenylcarbamate; HPLC: High-performance liquid chromatography; SPE: olid phase exteaction; LLE: Liquid-liquid extraction; LR: Linear rang.

In this study, a rapid, sensitive and enantioselective chiral HPLC-FL method was developed for determination of S-(-)- and R-(+)-VER utilizing a core-shell (superficially porous particle, SPP) isopropyl carbamate cyclofructan 6 chiral column in rat plasma after SPE, for the first time. The established assay exhibited excellent performance in terms of selectivity and efficiency $(3.5 \mathrm{~min})$ with a simple sample preparation. The validated assay employs a very low plasma volume $(50 \mu \mathrm{L})$ for processing and has a sensitivity $(1.0 \mathrm{ng} / \mathrm{mL}) 20$-fold lower than other reported HPLC methods for enantiomeric deter- 
mination of VER [30,31]. This assay was fully validated and successfully applied in a stereoselective pharmacokinetic study in rats after oral administration of VER racemate.

\section{Results and Discussion}

\subsection{Method Development and Optimization}

Superficially porous particles (core-shell) chiral stationary phases have revealed advantages in enantiomeric separations in HPLC owing to their superior effective separation with significantly reduced analysis times [4]. The polar organic mobile phase (POM) has been described as a mode to attain enantioselective resolution with derivatized CF-CSPs. This mode uses a non-aqueous polar solvent (acetonitrile) with both acetic acid and triethylamine, which are required to achieve difficult enantioseparation [12]. This study aimed to develop a novel chiral bioanalytical HPLC assay for the fast and sensitive determination of VER enantiomers, permitting a low level sensitivity $(1.0 \mathrm{ng} / \mathrm{mL})$ in plasma and ability to being used in stereoselective pharmacokinetic studies of VER in rats.

In previous HPLC studies, the chiral separations of VER enantiomers were achieved using $\alpha_{1}$-acid glycoprotein (AGP), cellulose tris(3,5-di-methylphenylcarbamate (Chiralcel OD-R) and amylose tris(3,5-di-methylphenylcarbamate (Chiralpak AD) CSPs that required a relatively long run time of approximately 34-40 min to attain acceptable chiral separation $[23,30,31]$. In this study, an effective alternative HPLC method using core shell isopropyl cabamate cyclofructan 6, LarihcShell-P, (LSP) CSP was established to provide higher efficiency and shorter analysis time to improve the throughput analysis.

The preliminary investigations were directed to use a conventional HPLC technique with three different fully porous derivatized CF-CSP columns and three different mobile phase modes to acquire an optimized separation and symmetrical peak shape for VER enantiomers and IS. The three fully porous derivatized CF-CSP columns included dimethylphenyl carbamate cyclofructan 7 (Larihc CF7-DMP), R-naphthylethyl carbamate cyclofructan 6 (Larihc CF6-RN) and isopropyl carbamate cyclofructan 6 (Larihc CF6-P) (150 $\mathrm{mm} \times 4.6 \mathrm{~mm}$ i.d, $5 \mu \mathrm{m}$ particle size) from AZYP, LLC. (Arlington, TX, USA). The screening mobile phase compositions were performed for these columns with normal phase mode (NP), reversed phase mode (RP) and polar organic mode (POM). The NP screening mobile phase consisted of heptane/ethanol/triethylamine (TEA) (70:30:0.1, v/v/v) and an acetonitrile (ACN)/acetate buffer $(\mathrm{pH} 4.0,20 \mathrm{mM})(70: 30, v / v)$ for RP. The POM screening mobile phase consisted of ACN/methanol (MeOH)/trifluoroacetic acid (TFA)/TEA (80:20:0.1:0.1, $v / v / v / v)$, examined at a flow rate of $0.5 \mathrm{~mL} / \mathrm{min}$. To assess when to use each solvent adjustment, the parameters that impact resolution (Rs) (retention factor $(k)$, selectivity $(\alpha)$, and efficiency (N)) were carefully studied and compared [51]. Subsequently, $\alpha$ was first targeted to increase Rs, $\alpha$ has a greater influence on Rs. As a whole, parameters like temperature and flow rate did not significantly increase $\alpha$ but they affected $\mathrm{N}$ and $k$. Consequently, a variety of mobile phase optimization factors such as acid-base ratio, salt concentration and an organic modifier were examined to improve Rs.

The separation of VER enantiomers was first attempted using CF7-DMP, CF6-RN and CF6-P columns with the above mentioned three mobile phase compositions. However, no chiral resolution was achieved on CF6-RN and CF7-DMP columns, but partial separation of VER enantiomers ( $\mathrm{Rs}=0.9)$ was observed on a CF6-P column with a mobile phase consisted of ACN/MOH/TFA/TEA (98:2:0.1:0.1, v/v/v). However, the tailing factors of the enantiomers were so large that a good peak could not be obtained, and the retention time was longer than $18 \mathrm{~min}$. Moreover, when the ratio of TFA/TEA became 0.05:0.025, $(v / v)$, the resolution of VER enantiomers improved $(\mathrm{Rs}=1.1)$, but the retention time was still longer (18 $\mathrm{min})$. An effective baseline separation of VER enantiomers ( $\mathrm{ss}=2.82)$, separation factor $(\alpha>1.15)$ and improved peak shape of the VER enantiomers with a short analysis time $(2.3 \mathrm{~min})$ were attained when the core-shell (superficially porous particle, SPP), LarihcShell-P (LSP) $(100 \mathrm{~mm} \times 2.1 \mathrm{~mm}$ i.d., $2.7 \mu \mathrm{m}$ particles $)$ CSP, with an isocratic mobile phase consisting of ACN/MOH/TFA/TEA (98:2:0.05: 0.025, v/v/v/v) at a flow rate of $0.5 \mathrm{~mL} / \mathrm{min}$ was applied. An adequate chiral chromatography separation with 
well-defined peaks for S-(-)-, R-(+)-VER, and IS in rat plasma was achieved with retention times of 1.95, 2.29, and 3.38 min for S-(-)-, R-(+)-VER, and IS; respectively, as shown in Figure 2 and Table 2.

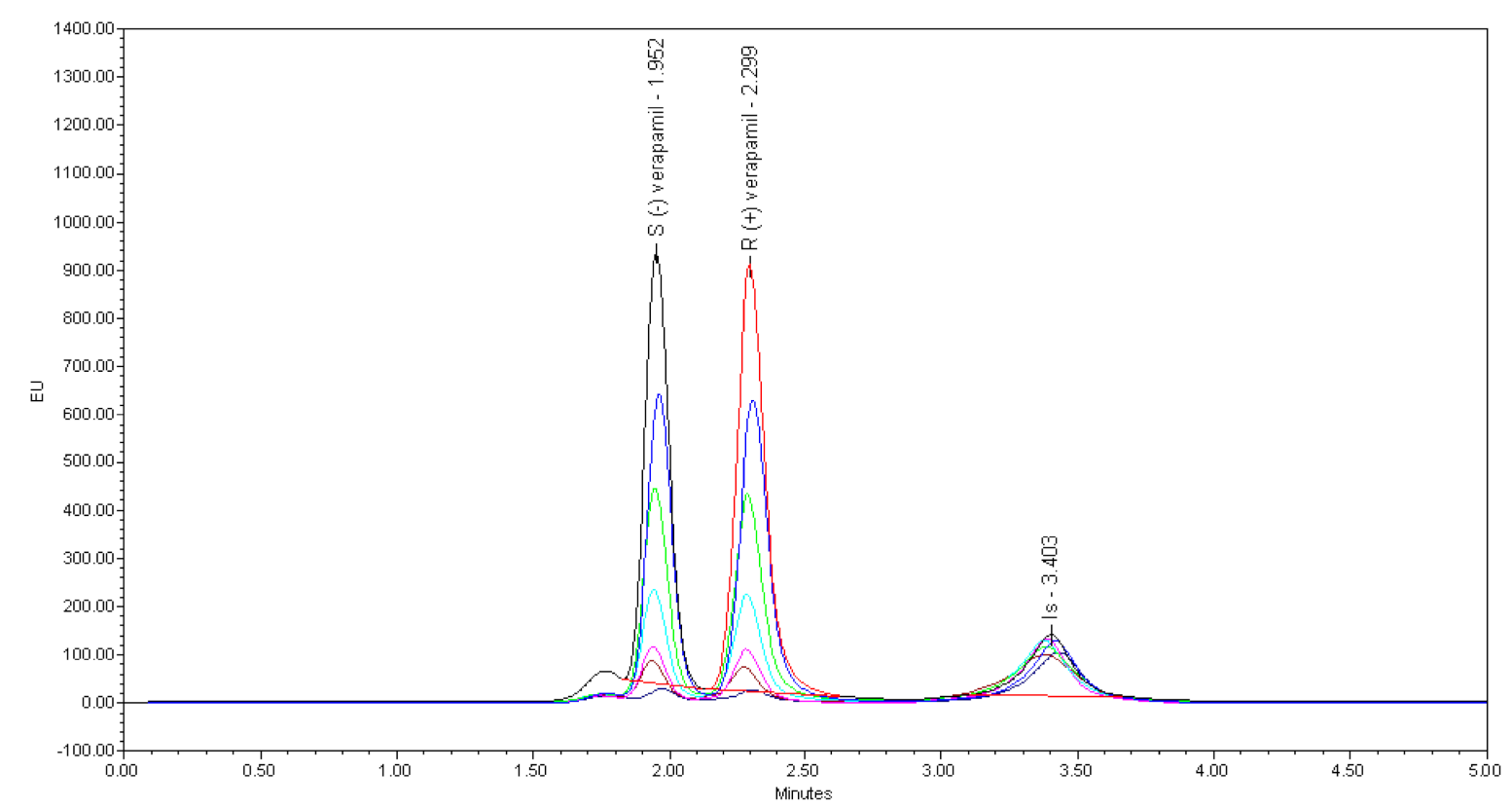

Figure 2. Representative overlaid HPLC chromatograms of the rat plasma analysis of S-(-)-verapamil (1.95 min), R-(+)verapamil (2.29 $\mathrm{min})(1.0-450 \mathrm{ng} / \mathrm{mL})$ and propranolol (3.38), (IS), (500 ng/mL).

Table 2. Chromatographic parameters of verapamil enantiomers and internal standard in rat plasma using the proposed method.

\begin{tabular}{ccccc}
\hline Analyte & $\mathbf{R}_{\mathbf{s}}{ }^{\mathbf{a}}$ & $\boldsymbol{\alpha}^{\mathbf{b}}$ & $\mathbf{k}^{\mathbf{c}}$ & $\mathbf{T}_{\mathbf{R}}(\mathbf{m i n}) \mathbf{d}^{\mathbf{d}} \mathbf{e}$ \\
\hline S-(-)-verapamil & $\mathrm{f}$ & 1.24 & $4.21 \pm 0.03$ & $1.95 \pm 0.04$ \\
\hline R-(+)-verapamil & 2.82 & 1.75 & $5.22 \pm 0.08$ & $2.29 \pm 0.07$ \\
\hline Propranolol (IS) & 8.68 & $\mathrm{f}$ & $9.13 \pm 0.04$ & $3.38 \pm 0.04$
\end{tabular}

$\bar{a} R_{s}=2\left(t_{2}-t_{1}\right) /\left(w_{1}+w_{2}\right)$, where $t_{2}$ and $t_{1}$ are the retention of the second and first peaks and $w_{1}$ and $w_{2}$ are the half peak width of the second and first peaks. ${ }^{\mathrm{b}}$ Separation factor, calculated as $\mathrm{k}_{2} / \mathrm{k}_{1} \cdot{ }^{\mathrm{c}}$ Retention capacity. ${ }^{\mathrm{d}} \mathrm{T}_{\mathrm{R}}=$ Retention time. ${ }^{\mathrm{e}}($ mean $\pm \mathrm{SD}) .{ }^{\mathrm{f}}$ Not calculated.

\subsection{Sample Pretreatment}

Sample pretreatment is critical for determination of analytes. Liquid-liquid extraction (LLE) and solid phase extraction (SPE) are common methods used for sample pretreatment [52]. LLE could not effectively remove the interferences caused by endogenous substances from the sample matrix, and it could not afford clean enough samples. In the current study, SPE was a useful extraction procedure related to LLE, which has been reported in the previous HPLC studies [23,25-27,31,33], where it provided less solvent consumption, was less time-consuming, and had low background noise and high recoveries of the S-(-)-, R-(+)-VER and IS from rat plasma. Five types of SPE cartridges (Water oasis HLB, CN, C18, C8 and C2) were examined for plasma sample cleanup. The eluting capabilities of numerous solvents toward VER enantiomers and IS were studied. Of these solvents, only $\mathrm{MeOH}$ rather than a mixture of $\mathrm{MeOH}$ with water or $\mathrm{ACN}$ was able to disrupt all types of interactions in the case of VER enantiomers and IS and thus to extract them from the C18 sorbent. High recoveries and clean chromatogram for S-(-)-, R-(+)-VER and IS were attained with the C18 cartridge. The recoveries ranged from 92.3-98.2 and 92.0-97.9 for S-(-)- and R-(+)-VER in the rat plasma, respectively. In the present study, propranolol was selected as IS because its physicochemical characteristics are similar to 
those of VER and it gave high recovery and good separate peaks from the S-(-)- and R-(+)-VER. Both drugs possess native fluorescence, similar solubilities in alcohols, and nearly similar $\log p$ values.

\subsection{In-Study Validation}

According to the guidelines of the US-FDA [53], method validation parameters, such as specificity, calibration curves, lower limit of quantification (LLOQ), intra- and inter-day accuracy and precision, extraction recovery and stability were evaluated.

The specificity of the developed HPLC-FL method was evaluated by comparing the chromatograms of blank plasma samples, the plasma samples spiked with VER enantiomers at LLOQ $(1 \mathrm{ng} / \mathrm{mL})$ for each enantiomer and real plasma samples collected at $2 \mathrm{~h}$ after oral administration of $10 \mathrm{mg} / \mathrm{kg}$ racemic VER. The typical chromatograms are shown in Figure 3B. The retention time of S-(-)-, R-(+)-VER, and IS were 1.95, 2.29, and $3.38 \mathrm{~min}$, respectively. No interfering peaks of endogenous components of the rat plasma were observed at the retention time of VER enantiomers and IS, which confirms that the validated method is specified.

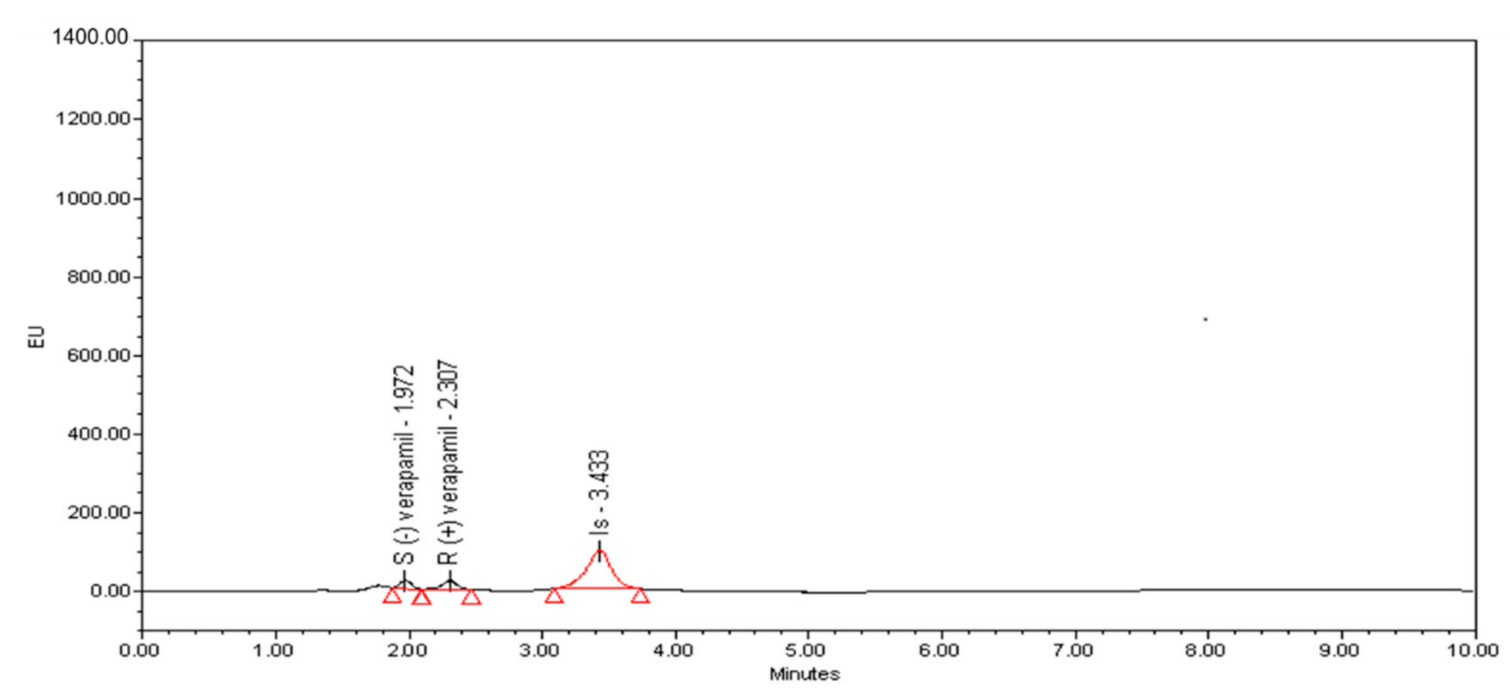

(A)

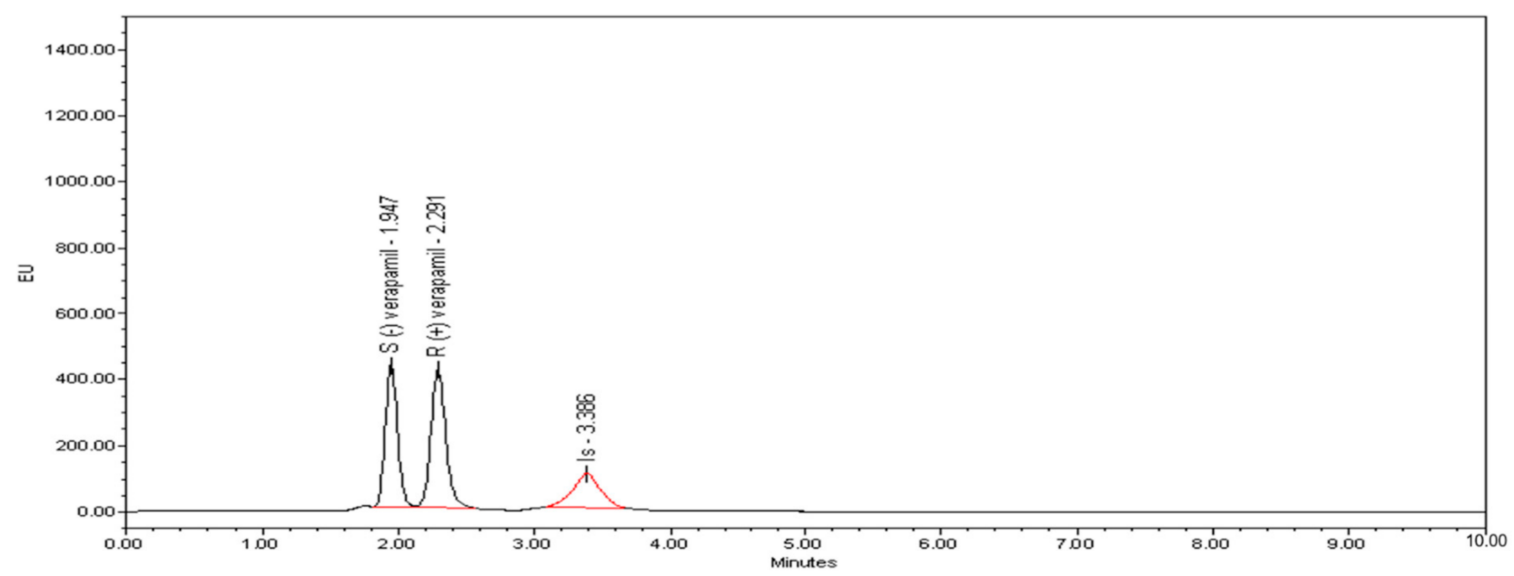

(B)

Figure 3. Representative HPLC chromatograms of blank plasma spiked with S-(-)- and R-(+)-verapamil at LLOQ level (A) and a plasma sample obtained at $2 \mathrm{~h}$ after a single dose of $10 \mathrm{mg} / \mathrm{kg}$ racemic verapamil (B).

Calibration curves for S-(-)-, R-(+)-VER enantiomers were validated in the concentration range of $1.0-450.0 \mathrm{ng} / \mathrm{mL}$ in rat plasma. The calibration curve was constructed by plotting the peak area ratio $(y)$ of each enantiomer to the IS versus the spiking con- 
centrations $(x)$ of each enantiomer. The regression equations achieved by least squared regression for S- $(-)$ - and $\mathrm{R}-(+)-$ VER were; $\mathrm{y}=0.0014 \mathrm{x}+0.0121, \mathrm{r}^{2}=0.998$; and $\mathrm{y}=0.0018 \mathrm{x}+$ $0.0192, \mathrm{r}^{2}=0.997$, for S-(-)- and R-(+)-VER, respectively (Table 3$)$. The LLOQ of each VER enantiomer was recognized as $1 \mathrm{ng} / \mathrm{mL}$. These results confirmed that the developed assay was proper for the research on the enantioselective pharmacokinetics of VER in rat.

Table 3. Statistical parameters of calibration curves for S-(-)- and R-(+)-verapamil in rat plasma using the developed method.

\begin{tabular}{ccc}
\hline Parameters & S-(-)-Verapamil & R-(+)-Verapamil \\
\hline Concentration range (ng/mL) & $1-450$ & $1-450$ \\
Intercept (a) & $1.21 \times 10^{-2}$ & $1.91 \times 10^{-2}$ \\
Slope (b) & $1.45 \times 10^{-3}$ & $1.81 \times 10^{-3}$ \\
Coefficient of determination (r2) & 0.998 & 0.997 \\
$\mathrm{~S} \mathrm{Y/N}{ }^{\mathrm{a}}$ & $7.39 \times 10^{-3}$ & $6.88 \times 10^{-3}$ \\
$\mathrm{Sa}^{\mathrm{b}}$ & $4.52 \times 10^{-3}$ & $3.29 \times 10^{-3}$ \\
$\mathrm{Sb}^{\mathrm{c}}$ & $2.74 \times 10^{-3}$ & $5.14 \times 10^{-3}$ \\
LLOQ $(\mathrm{ng} / \mathrm{mL})$ & 1.0 & 1.0 \\
LLOD $(\mathrm{ng} / \mathrm{mL})$ & 0.3 & 0.3 \\
\hline
\end{tabular}

a $\mathrm{SD}$ of the residual. ${ }^{\mathrm{b}} \mathrm{SD}$ of the intercept. ${ }^{\mathrm{c}} \mathrm{SD}$ of the slope.

The intra- and inter-day precision and accuracy values for QC samples (LLOQ, LQC, MQC, HQC) of S-(-)- and R-(+)-VER are summarized in Table 4. Precision was determined by the relative standard deviation (RSD), while the relative error (RE) was employed to estimate the accuracy. The RSD values of intra- and inter-day precision for S-(-)-VER were $<11.7 \%$, whereas the RE values of accuracy vary from -1.0 to $5.3 \%$. For R-(+)-VER, the RSD values of intra- and inter-day precision were within $9.8 \%$, while the RE values of accuracy ranged from -3.1 to $3.6 \%$. At LLOQ, the RSD for both intra- and inter-assay precision was not more than $10.2 \%$ and $8.2 \%$ for S-(-)- and R-(+)-VER; respectively. These data demonstrated that the optimized assay revealed satisfactory precision and accuracy.

Table 4. Precision and accuracy data for analysis of verapamil enantiomers in rat plasma (3 days with 6 replicates per day).

\begin{tabular}{|c|c|c|c|c|c|c|c|c|}
\hline \multirow[t]{2}{*}{ Analyte } & & & \multicolumn{3}{|c|}{ Intra-Day } & \multicolumn{3}{|c|}{ Inter-Day } \\
\hline & & $\begin{array}{c}\text { Nominal Conc. } \\
(\mathrm{ng} / \mathrm{mL})\end{array}$ & $\begin{array}{c}\text { Mean } \\
(\mathrm{ng} / \mathrm{mL})\end{array}$ & $\begin{array}{l}\text { Precision } \\
\text { (RSD, \%) }\end{array}$ & $\begin{array}{l}\text { Accuracy } \\
\text { (RE, \%) }\end{array}$ & $\begin{array}{c}\text { Mean } \\
(\mathrm{ng} / \mathrm{mL})\end{array}$ & $\begin{array}{l}\text { Precision } \\
\text { (RSD, \%) }\end{array}$ & $\begin{array}{c}\text { Accuracy } \\
\text { (RE, \%) }\end{array}$ \\
\hline \multirow{4}{*}{$\begin{array}{c}\text { S-(-)- } \\
\text { verapamil }\end{array}$} & LLOQ & 1 & $1.03 \pm 0.10$ & 9.72 & 3.00 & $1.04 \pm 0.08$ & 7.69 & 4.00 \\
\hline & QCL & 3 & $3.14 \pm 0.33$ & 10.41 & 4.66 & $3.16 \pm 0.36$ & 11.61 & 5.33 \\
\hline & QCM & 200 & $197.00 \pm 7.3$ & 3.82 & -1.50 & $198.00 \pm 7.54$ & 3.81 & -1.00 \\
\hline & $\mathrm{QCH}$ & 400 & $390.00 \pm 8.55$ & 2.19 & -2.50 & $387.08 \pm 12.04$ & 3.11 & -3.23 \\
\hline \multirow{4}{*}{$\begin{array}{c}\mathrm{R}-(+)- \\
\text { verapamil }\end{array}$} & LLOQ & 1 & $1.04 \pm 0.11$ & 10.19 & 4.00 & $1.05 \pm 0.09$ & 8.14 & 5.00 \\
\hline & $\mathrm{QCL}$ & 3 & $3.11 \pm 0.28$ & 9.15 & 3.66 & $3.09 \pm 0.30$ & 9.82 & 3.00 \\
\hline & QCM & 200 & $197.22 \pm 8.30$ & 4.21 & 1.39 & $196.50 \pm 7.29$ & 3.71 & 1.75 \\
\hline & QCH & 400 & $387.60 \pm 11.43$ & 2.95 & -3.10 & $390.68 \pm 10.97$ & 2.81 & -2.33 \\
\hline
\end{tabular}

The extraction recoveries were assessed by comparing the peak areas obtained from pre-extracted plasma samples spiked with S-(-)- and R-(+)-VER and post-extracted plasma samples spiked with analytes. The recoveries of S-(-)- and R-(+)-VER at three QC levels $(3,200$ and $400 \mathrm{ng} / \mathrm{mL})$ and IS (500 ng/mL) ranged from $92.3 \%$ to $98.2 \%$ and from $92.0 \%$ to $97 \%$ with all RSD values within $9.5 \%$ (Table 5). The extraction recoveries of IS at 500 $\mu \mathrm{g} / \mathrm{mL}$ in plasma were $>94 \%$. 
Table 5. Extraction recovery for the analysis of S-(-)- and R-(+)-verapamil and IS in rat plasma by the proposed method.

\begin{tabular}{cccccccc}
\hline \multirow{2}{*}{$\begin{array}{c}\text { Nominal } \\
\text { Concentration (ng/mL) }\end{array}$} & \multicolumn{3}{c}{ S-(-)-Verapamil } & \multicolumn{2}{c}{ R-(+)-Verapamil } & IS \\
\cline { 2 - 8 } & $\mathbf{3}$ & $\mathbf{2 0 0}$ & $\mathbf{4 0 0}$ & $\mathbf{3}$ & $\mathbf{2 0 0}$ & $\mathbf{4 0 0}$ & $\mathbf{5 0 0}(\mathbf{n g} / \mathbf{m L})$ \\
\hline Mean $^{\mathrm{a}}$ & 2.77 & 191.50 & 392.88 & 2.76 & 193.70 & 391.64 & 470.55 \\
\hline RSD & 9.51 & 4.22 & 2.71 & 7.19 & 3.82 & 2.83 & 8.91 \\
\hline Recovery (\%) & 92.33 & 95.75 & 98.22 & 92.00 & 96.85 & 97.91 & 94.70 \\
\hline Mean recovery (\%) & & 95.58 & & & 94.92 & & 94.11 \\
\hline a mean of six measurements. & & & & &
\end{tabular}

Stability of the S-(-)- and R-(+)-VER enantiomers in rat plasma at the two different concentration levels (LQC, HQC) during the sample storing and processing procedures was fully assessed and the results are summarized in Table 6 . The data of stability tests showed that S-(-)- and R-(+)-VER were stable at room temperature for $24 \mathrm{~h}$ (short-term stability) and at $-80^{\circ} \mathrm{C}$ for 30 days (long-term stability). To examine autosampler stability, samples were retained in an automatic sampling room at $10^{\circ} \mathrm{C}$ for $24 \mathrm{~h}$. For freeze-thaw stability, samples were frozen at $-80^{\circ} \mathrm{C}$ for $24 \mathrm{~h}$ and then thawed to room temperature for three cycles. As per the stability conditions, the accuracy in plasma ranged from $-6.2 \%$ to $2.9 \%$ and $-7.6 \%$ to $4.4 \%$ for S-(-)- and R-(+)-VER, respectively. The results confirmed that the VER enantiomers maintained stability in plasma samples under different storage conditions.

Table 6. Stability results for S-(-)- and R-(+)-verapamil in rat plasma under different storage conditions.

\begin{tabular}{|c|c|c|c|c|c|c|c|c|c|c|}
\hline \multirow[t]{2}{*}{ Analyte } & \multicolumn{2}{|c|}{$\begin{array}{l}\text { Concentration } \\
(\mathrm{ng} / \mathrm{mL})\end{array}$} & \multicolumn{2}{|c|}{$\begin{array}{c}\text { Short Term Stability } \\
\text { at Room Temperature } \\
(24 \mathrm{~h})\end{array}$} & \multicolumn{2}{|c|}{$\begin{array}{c}\text { Freeze and Thaw } \\
\text { Stability at }-80^{\circ} \mathrm{C} \\
\quad(3 \text { cycles })\end{array}$} & \multicolumn{2}{|c|}{$\begin{array}{l}\text { Long Term Stability } \\
\text { at }-80^{\circ} \mathrm{C}(30 \text { days })\end{array}$} & \multicolumn{2}{|c|}{$\begin{array}{c}\text { Autosampler } \\
\text { Stability at } 10^{\circ} \mathrm{C} \\
(24 \mathrm{~h})\end{array}$} \\
\hline & & & RE (\%) & RSD (\%) & RE (\%) & RSD (\%) & RE (\%) & RSD (\%) & RE (\%) & RSD (\%) \\
\hline \multirow{2}{*}{$\begin{array}{c}\text { S-(-)- } \\
\text { verapamil }\end{array}$} & QCL & 3 & -5.11 & 9,70 & -6.22 & 11.40 & -4.82 & 11.31 & -5.21 & 9.29 \\
\hline & $\mathrm{QCH}$ & 400 & 1.42 & 1.81 & 2.63 & 6.52 & 2.91 & 3.85 & 0.75 & 3.24 \\
\hline \multirow{2}{*}{$\begin{array}{c}\mathrm{R}-(+)- \\
\text { verapamil }\end{array}$} & QCL & 3 & -4.73 & 10.61 & -7.61 & 11.52 & -5.35 & 5.52 & -3.82 & 5.29 \\
\hline & $\mathrm{QCH}$ & 400 & 1.29 & 2.76 & 4.34 & 6.35 & 2.52 & 4.45 & 3.73 & 4.44 \\
\hline $\mathrm{N}$ & & & 3 & & 3 & & 3 & & 3 & \\
\hline
\end{tabular}

\subsection{Application to an Enantioselective Pharmacokinetic Study}

The applicability of the developed method in this study was established through the determination of S-(-)- and R-(+)-VER in rat plasma after oral (gavage) administration of $10 \mathrm{mg} / \mathrm{kg}$ racemic verapamil [54]. The typical chromatograms of rat plasma at $2.0 \mathrm{~h}$ after oral administration are shown in Figure 3B. The curve of mean plasma concentration over time of VER enantiomers is presented in Figure 4, and the individual differences in the pharmacokinetic (PK) parameters of the S-(-)- and R-(+)-VER are summarized in Table 7. Differences in PK parameters were considered statistically significant at $p<0.05$, by comparing paired sample T-tests. By comparing the drug concentration-time curves of the S-(-)- and R-(+)-VER more precisely, we found that the mean $C_{\max }$ value of S-(-)-VER was 3.2 times higher than that of R-(+)-VER, and the area under the plasma concentration versus time curve $\left(\mathrm{AUC}_{0-\infty}\right)$ was 3 -fold higher than that of $\mathrm{R}-(+)-\mathrm{VER}$, which repeatedly verified that S-(-)-VER offered the greater pharmacodynamic activity compared with $\mathrm{R}-(+)-\mathrm{VER}$. These results are consistent with in vivo rac-verapamil PK data from previous studies $[19,55]$ in which the S-isomer form of VER is almost totally responsible for the slowing cardiac conduction velocity. Moreover, the plasma concentration of S-(-)-VER after oral administration had always been much higher than that of R-(+)-VER, which 
might be beneficial if S-(-)-VER performs the pharmacodynamic action in vivo. This study justified the conclusion that the pharmacokinetics of the VER enantiomers after oral administration of racemic VER were stereoselective. The use of rats in this work instead of humans was because of the significant correlation between the lipoprotein lipid and protein profiles in humans and rats [56].

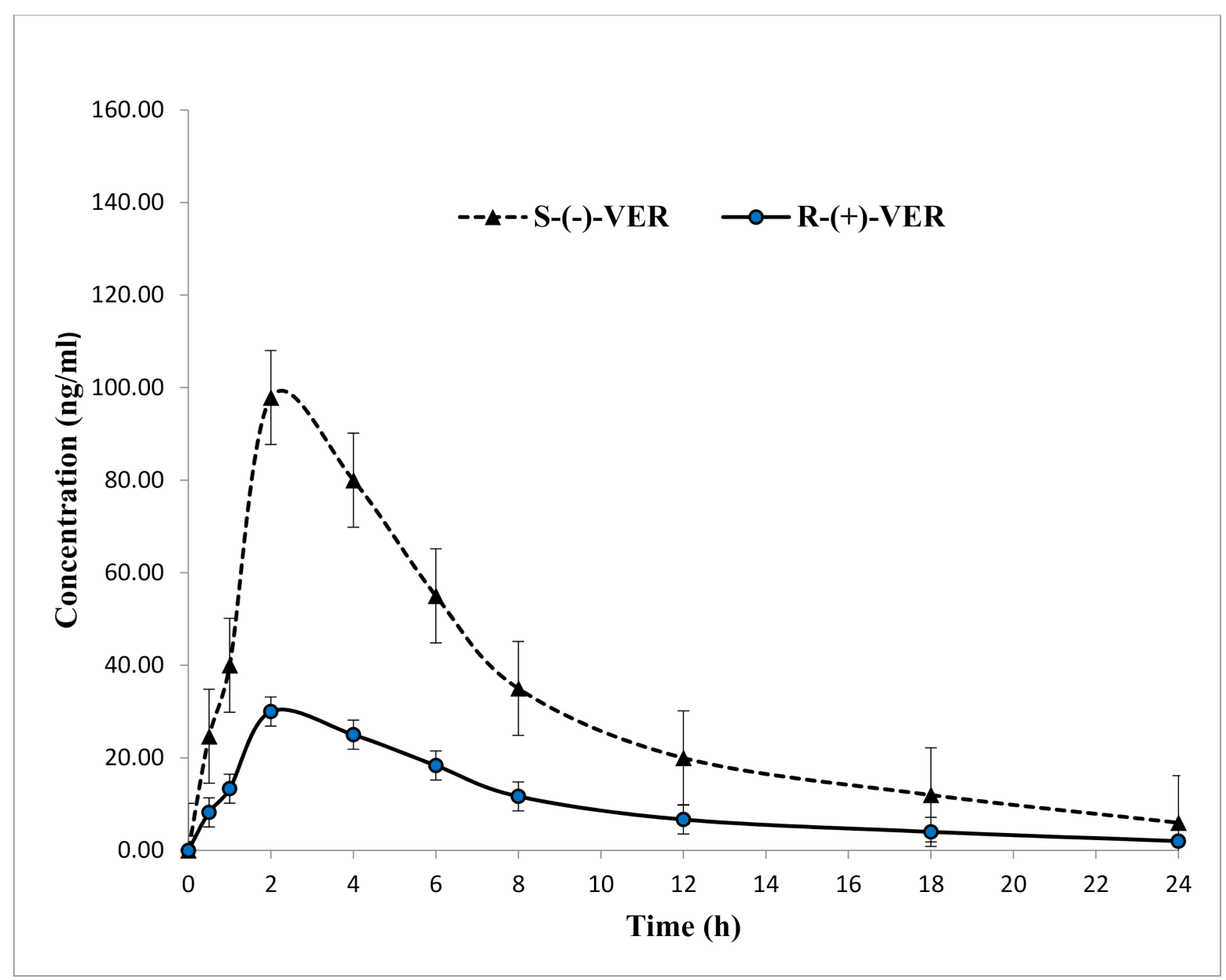

Figure 4. Mean plasma concentration-time profile of S-(-)- and R-(+)-verapamil after oral (gavage) administration of $10 \mathrm{mg} / \mathrm{kg}$ racemic verapamil hydrochloride to Sprague-Dawley rats, $(n=6$, mean $\pm \mathrm{SD})$.

Table 7. The enantioselective pharmacokinetic parameters of S-(-)- and R-(+)-verapamil in the plasma of rats treated with a single dose of $10 \mathrm{mg} / \mathrm{kg}$ racemic verapamil hydrochloride (gavage), $(n=5$, Mean $\pm \mathrm{SD})$.

\begin{tabular}{cccc}
\hline Parameter & Unit & S-(-)-VER * & R-(+)-VER * \\
\hline AUC0-t $^{\mathrm{a}}$ & $\mathrm{ng} / \mathrm{mL} \cdot \mathrm{h}$ & $754.10 \pm 150.82$ & $244.10 \pm 48.82$ \\
$\mathrm{AUC0}-\infty^{\mathrm{b}}$ & $\mathrm{ng} / \mathrm{mL} \cdot \mathrm{h}$ & $810.30 \pm 162.95$ & $262.82 \pm 52.51$ \\
$\mathrm{Cmax}{ }^{\mathrm{c}}$ & $\mathrm{ng} / \mathrm{mL}$ & $97.85 \pm 19.62$ & $30.25 \pm 6.43$ \\
$\mathrm{Tmax}^{\mathrm{d}}$ & $\mathrm{h}$ & $2.00 \pm 0.41$ & $2.00 \pm 0.41$ \\
$\mathrm{Cl} / \mathrm{F}^{\mathrm{e}}$ & $\mathrm{ng} / \mathrm{mL} \cdot \mathrm{h}$ & $12.34 \pm 2.47$ & $38.05 \pm 7.61$ \\
$\mathrm{t}_{1 / 2}{ }^{\mathrm{f}}$ & $\mathrm{h}$ & $6.50 \pm 1.30$ & $6.50 \pm 1.33$ \\
$\mathrm{MRT}_{0-\infty}$ & $\mathrm{h}$ & $8.97 \pm 1.80$ & $9.14 \pm 1.83$ \\
\hline
\end{tabular}

${ }^{*}$ Data are presented as mean \pm SD. ${ }^{a}$ Area under the concentration-time curve to the last measurable concentration. ${ }^{b}$ Area under the plasma concentration-time curve to infinity. ${ }^{c}$ Maximum plasma concentration. ${ }^{d}$ Time to reach maximum plasma concentration. ${ }^{\mathrm{e}}$ Total body clearance. ${ }^{\mathrm{f}}$ Elimination half-life. ${ }^{\mathrm{g}}$ Mean residence time. 


\section{Materials and Methods}

\subsection{Chemicals and Reagents}

S-(-)-, R-(+)-verapamil and racemic-verapamil hydrochloride (99.0\%, purity) were purchased from Toronto Research Chemicals (Toronto, ON, Canada). Propranolol (internal standard, IS, 98.0\% purity) was obtained from Sigma-Aldrich (St. Louis, MO, USA). HPLCgrade methanol and acetonitrile LiChrosolv ${ }^{\circledR}(99.0 \%$ purity) were from Merck (Darmstadt, Germany). Trifluoroacetic acid and triethylamine (98\% purity) were purchased from SigmaAldrich (Zwijndrecht, The Netherlands). All other chemicals and solvents were obtained from BDH Chemicals (Poole, UK). The water used was purified by a Milli-Q Millipore Water System (Millipore, Billerica, MA, USA). Oasis HLB and Sep-Pak cartridges CN, C18, C8 and C2 (1 mL) were obtained from Waters Corp. (Milford, MA, USA).

\subsection{Chromatographic Conditions}

Chromatographic analysis was achieved on a Waters Corporation System (Milford, MA, USA), equipped with a binary pump (Waters 1525), an autosampler (Waters 2707), a dual wavelength fluorescence detector (Waters 2475) and an Empower Pro Chromatography Manager software (Waters Corporation) for data acquisition. The signal was monitored at $280 \mathrm{~nm}$ for excitation and $313 \mathrm{~nm}$ for emission. The chiral chromatographic separation was carried out at $21 \pm 2{ }^{\circ} \mathrm{C}$ on an isopropyl carbamate cyclofructan 6 (superficially porous particle, SPP) analytical chiral column (LarihcShell-P, LSP) $(100 \mathrm{~mm} \times 2.1 \mathrm{~mm}$ i.d., $2.7 \mu \mathrm{m}$ particles), purchased from AZYP, LLC. (Arlington, TX, USA) with a guard column of LarihcShell-P, LSP (3.0 mm i.d. $\times 10 \mathrm{~mm}, 2.7 \mu \mathrm{m}$ particles, AZYP, Arlington, TX, USA). The mobile phase was acetonitrile/methanol/trifluoroacetic acid/triethylamine (98:2:0.05: $0.025, v / v / v / v)$ at a flow rate of $0.5 \mathrm{~mL} / \mathrm{min}$. The injection volume was $5.0 \mu \mathrm{L}$ and total run time was $3.5 \mathrm{~min}$. The mobile phases and drug solutions were filtered through a 0.22 $\mu \mathrm{m}$ Millex filter (EMD Millipore, Milford, MA, USA) and degassed in an ultrasonic bath (Tecnal, São Paulo, Brazil). Three fully porous derivatized CF-CSP columns from AZYP (Arlington, TX, USA) with the following characterization: $150 \mathrm{~mm} \times 4.6 \mathrm{~mm}$ i.d, $5 \mu \mathrm{m}$ particle size, were used for a comparison study of R-naphthylethyl carbamate cyclofructan 6 (Larihc CF6-RN), isopropyl carbamate cyclofructan 6 (Larihc CF6-P) and dimethylphenyl carbamate cyclofructan 7 (Larihc CF7-DMP).

\subsection{Animals}

Male Sprague-Dawley rats (250-290 g) were procured from the Animal Care Center of King Saud University (Riyadh, Saudia Arabia), and were utilized to gather blank plasma and to conduct the pharmacokinetic studies. The blank plasma was obtained by centrifuging drug-free rat blood for $10 \mathrm{~min}$ at $2500 \times \mathrm{g}$, then storing it at $-80{ }^{\circ} \mathrm{C}$ until analysis. All the animal experimental procedures involving animal handling were carried out according to the ethical guidelines for experimental studies with animals according to the Institutional Animal Care and Use Committee (IACUC) guidelines, King Saud University, with ethical approval number KSU-SE-19-11.

\subsection{Sample Preparation}

\subsubsection{Preparation of Stock and Standard Solutions}

The methanol was used for preparing the $1 \mathrm{mg} / \mathrm{mL}$ stock solutions of the S-(-)- and R(+)-VER (free base) and propranolol (IS). Working solutions of the S-(-)- and R-(+)-VER at concentrations of $0.1,1$, and $10 \mu \mathrm{g} / \mathrm{mL}$ (intermediate solutions) were prepared by diluting its stock solutions with methanol. The working solution of IS $(500 \mathrm{ng} / \mathrm{mL})$ was achieved by diluting the stock solution with methanol. All standard solutions were stored at $-20^{\circ} \mathrm{C}$.

\subsubsection{Preparation of Calibrators and Quality Control Samples}

Calibrators at concentrations of 1, 5, 10, 50, 100, 250 and $450 \mathrm{ng} / \mathrm{mL}$ for S-(-)- and $\mathrm{R}-(+)$-VER were prepared in drug-free rat plasma from the intermediate solutions. Quality 
control (QC) samples at low (3 ng/mL), medium (200 ng/mL), and high $(400 \mathrm{ng} / \mathrm{mL})$ blank plasma concentrations of VER enantiomer were prepared.

\subsection{Sample Pretreatment}

Plasma $(50 \mu \mathrm{L})$ in a $2 \mathrm{~mL}$ disposable polypropylene micro centrifuge tube containing $1 \mathrm{~mL}$ of phosphate buffer $(0.05 \mathrm{mM}, \mathrm{pH} 9.0)$ was spiked with $50 \mu \mathrm{L}$ of propranolol (IS) $(500 \mathrm{ng} / \mathrm{mL}$ ). The tube was twisted for $30 \mathrm{~s}$. Oasis HLB (Waters) cartridges were attached to a vacuum manifold (VacElute, Harbor City, CA, USA) and conditioned with $2 \times 500 \mu \mathrm{L}$ of methanol and $2 \times 500 \mu \mathrm{L}$ of deionized water. Care was taken to assure that the cartridges did not dry out. The buffered blank and plasma sample was loaded into the cartridges and a vacuum was applied to gain a flow rate of $0.5 \mathrm{~mL} / \mathrm{min}$. The cartridges were washed with $2 \times 500 \mu \mathrm{L}$ of deionized water, then dried under pressure (15 psi) for $3 \mathrm{~min}$. The analytes were eluted with $2 \times 100 \mu \mathrm{L}$ of methanol and $5 \mu \mathrm{L}$ was injected into the HPLC system.

\subsection{Pre-Study Validation}

Intensive validation studies for analyzing S-(-)-, R-(+)-VER in rat plasma were performed following the US-FDA guidelines [53]. The studied validation parameters in the rat plasma included specificity, linearity and sensitivity, accuracy and precision, recovery, influence of co-elution of enantiomers and stability.

The specificity of the developed HPLC-FL method was examined by evaluating the interference levels of endogenous components in blank rat plasma from six individuals. Levels of less than $20 \%$ of the LLOQ for S-(-)-, R-(+)-VER and $<5 \%$ of the IS were accepted [53].

The linearity of the calibration curves in plasma, described as $y=a+b x$, was established using seven concentrations of S-(-)- and R-(+)-VER enantiomer; 1, 5, 10, 50, 100, 250 and $450 \mathrm{ng} / \mathrm{mL}$, on three separate days. The lowest concentration of the calibration curve $(S / N \geq 10)$ was utilized for determining the LLOQ.

Intra- and inter-day precision and accuracy were assessed by assaying six replicates of spiked plasma samples at the lower limit (LLOQ) $(1 \mathrm{ng} / \mathrm{mL})$, in addition to three different QC levels (3, 200, and $400 \mathrm{ng} / \mathrm{mL}$ ) for each enantiomer, on three successive days (interday, $\mathrm{n}=3$ ) and one day (intra-day, $\mathrm{n}=3$ ). The accuracy was expressed as RE (\%) and the precision as RSD (\%). The impact of the co-elution of S-(-)-VER and R-(+)-VER on the method values was assessed by subjecting plasma samples containing high levels of S-(-)-VER and low levels of R-(+)-VER (or vice versa) to the analysis.

The extraction recovery of S-(-)- and R-(+)-VER enantiomers in plasma was examined by comparing the peak areas obtained from blank plasma samples spiked with the analytes before extraction with those of spiked post-extraction at three QC levels (LQC, MQC, and HQC) in six replicates. Moreover, the extraction recovery of the IS at the same concentration level of the method was calculated.

The stability of S-(-)-VER and R-(+)-VER in rat plasma was evaluated using QC samples at LQC, MQC, and HQC in three replicates. The QC samples were kept at room temperature for $24 \mathrm{~h}$ and at $-80^{\circ} \mathrm{C}$ for 30 days to evaluate the short-and long-term stability, respectively. The freeze-thaw stability examination was investigated after exposing the unextracted QC samples to three freeze-thaw cycles $\left(3\right.$ cycles, $\left.-80^{\circ} \mathrm{C}\right)$. The post preparative stability was tested in an autosampler at $10^{\circ} \mathrm{C}$ for $24 \mathrm{~h}$.

\subsection{Stereoselective Pharmacokinetic Studies}

The validated HPLC-FL method was used to investigate the stereoselective pharmacokinetic (PK) study of VER enantiomers in rats. Six male Sprague-Dawley rats (250-290 g) were fasted for $12 \mathrm{~h}$ before the experiment, while water was allowed ad libitum. On the day of experiments, rats were treated by gavage administration with a single oral dose of $10 \mathrm{mg} / \mathrm{kg}$ rac-verapamil hydrochloride dissolved in $0.9 \%$ saline [54]. Blood samples $(300 \mu \mathrm{L})$ were collected into tubes containing di-sodium EDTA at the following time points: 0 (before administration), $0.5,1,2,4,6,8,12,18$ and $24 \mathrm{~h}$. The plasma was separated 
and collected by centrifuging blood at $2500 \times g$ for $10 \mathrm{~min}$ and transferred to pre-labeled Eppendorf tubes and kept at $-80^{\circ} \mathrm{C}$ until analysis. The PK parameters were calculated by fitting the data to a noncompartmental analysis (NCA) model with PK Solver Add-In software [57].

\section{Conclusions}

In this study, a rapid, sensitive and accurate HPLC-FL method was developed to analyze verapamil enantiomers in rat plasma after SPE for the first time. The established assay provided enough separation for verapamil enantiomers using a new core-shell isopropyl carbamate cyclofructan 6 (superficially porous particle, SPP) chiral column (LarihcShell-P, LSP) in the polar organic mode. The LLOQ of each verapamil enantiomer was established to be $1 \mathrm{ng} / \mathrm{mL}$, which was significantly lower than the previous report $[30,31](20 \mathrm{ng} / \mathrm{mL})$. The whole analysis process was within $3.5 \mathrm{~min}$, which is 10-fold lower than the previous reported HPLC methods in the literature [23,30,31]. After validation, the developed method was applied to the enantioselective pharmacokinetic study of verapamil enantiomers after oral administration of $10 \mathrm{mg} / \mathrm{kg}$ racemic verapamil to Wistar rats. It was found that AUC, $\mathrm{C}_{\max }$, and clearance values of $\mathrm{S}-(-)$-verapamil were prominently higher than those of $\mathrm{R}-(+)$-verapamil, indicating the enantioselective pharmacokinetic behavior of verapamil in rats.

Author Contributions: Conceptualization, writing and original draft, M.M.H., M.S.M. and A.A.A.-M.; methodology and investigation, H.K.A. and N.A.A.; data analysis, A.J.O. and A.M.A.-H.; data analysis, A.S.A. and M.S.M.; pharmacokinetic study, Y.A.B.J.; writing-reviewing and editing, equal contribution of all authors; project administration, M.M.H.; funding acquisition, M.M.H., M.S.M. and A.M.A.-H. All authors have read and agreed to the published version of the manuscript.

Funding: This study was funded by the Deanship of Scientific Research at King Saud University through the Research Group Project no. RGP-VPP-037.

Institutional Review Board Statement: The study was conducted according to the guidelines of the Declaration of Helsinki, and approved by the Institutional Animal Care and Use Committee (IACUC) guidelines, King Saud University, with ethical approval number KSU-SE-19-11.

Informed Consent Statement: Not applicable.

Data Availability Statement: Not applicable.

Acknowledgments: The authors extend their appreciation to the Deanship of Scientific Research at King Saud University for funding the work through the research group project no. RGP-VPP-037.

Conflicts of Interest: The authors declare no conflict of interest.

Sample Availability: Samples of the compounds are not available from the authors.

\section{References}

1. Ibrahim, A.; Hashem, H.; Elhenawee, M.; Saleh, H. Comparison between core-shell and totally porous particle stationary phases for fast and green LC determination of five hepatitis-C antiviral drugs. J. Sep. Sci. 2018, 41, 1734-1742. [CrossRef] [PubMed]

2. Avela, H.; Siren, H. Advances in analytical tools and current statistical methods used in ultra-high-performance liquid chromatography-mass spectrometry of glycero-, glycerophospho- and sphingolipids. Int. J. Mass Spectrom. 2020, 457, 116408. [CrossRef]

3. Lesko, M.; Samuelsson, J.; Asberg, D.; Kaczmarskib, K.; Fornstedt, T. Evaluating the advantages of higher heat conductivity in a recently developed type of core-shell diamond stationary phase particle in UHPLC. J. Chromatogr. A 2020, 1625, 461076. [CrossRef] [PubMed]

4. Roy, D.; Armstrong, D.W. Fast super/subcritical fluid chromatographic enantioseparations on superficially porous particles bonded with broad selectivity chiral selectors relative to fully porous particles. J. Chromatogr. A 2019, 1605, 360339. [CrossRef]

5. Gumustas, M.; Zalewski, P.; Ozkan, S.; Uslu, B. The history of the core-shell particles and applications in active pharmaceutical ingredients via liquid chromatography. Chromatographia 2019, 82, 17-48. [CrossRef]

6. Broeckhoven, K.; Cabooter, D.; Desmet, G. Kinetic performance comparison of fully and superficially porous particles with sizes ranging between $2.7 \mu \mathrm{m}$ and $5 \mu \mathrm{m}$ : Intrinsic evaluation and application to a pharmaceutical test compound. J. Pharm. Anal. 2013, 3, 313-323. [CrossRef] 
7. Tanaka, N.; McCalley, D.V. Core-shell, ultra small particles, monoliths and other support materials in HPLC. Anal. Chem. 2015, 88, 279-298. [CrossRef]

8. Hetzel, T.; Loeker, D.; Teutenberg, T.; Schmidt, T.C. Characterization of the efficiency of microbore LC columns by Van Deemter and kinetic plot analysis. J. Sep. Sci. 2016, 39, 3889-3897. [CrossRef]

9. Urio, R.P.; Masini, J.C. Evaluation of monolithic and core-shell columns for separation of triazine herbicides by reversed phase HPLC. J. Braz. Chem. Soc. 2015, 26, 2331-2338.

10. Elkurdi, S.; Abumuaileq, D.; Alhazmi, H.; Albratty, M.; Eldeeb, A. Comparing monolithic and fused core HPLC columns for fast chromatographic analysis of fat-soluble vitamins. Acta Pharm. 2017, 67, 203-213.

11. Barhate, C.L.; Lopez, D.A.; Makarov, A.A.; Bu, X.; Morris, W.J.; Lekhal, A.; Hartman, R.; Armstrong, D.W.; Regalado, E.L. Macrocyclic glycopeptide chiral selectors bonded to core-shell particles enables enantiopurity analysis of the entire verubecestat synthetic route. J. Chromatogr. A 2018, 1539, 87-92. [CrossRef]

12. Hellinghausen, G.; Roy, D.; Lee, J.T.; Wang, Y.; Weatherly, C.A.; Lopez, D.A.; Nguyen, K.A.; Armstrong, J.D.; Armstrong, D.W. Effective methodologies for enantiomeric separations of 150 pharmacology and toxicology related $1^{\circ}, 2^{\circ}$, and $3^{\circ}$ amines with core-shell chiral stationary phases. J. Pharm. Biomed. Anal. 2018, 155, 70-81. [CrossRef]

13. Patel, D.C.; Breitbach, Z.S.; Yu, J.; Nguyen, K.A.; Armstrong, D.W. Quinine bonded to superficially porous particles for highefficiency and ultrafast liquid and supercritical fluid chromatography. Anal. Chim. Acta 2017, 963, 164-174. [CrossRef]

14. Patel, D.C.; Wahab, M.F.; Armstrong, D.W.; Breitbach, Z.S. Advances in high-throughput and high-efficiency chiral liquid chromatographic separations. J. Chromatogr. A 2016, 1467, 2-18. [CrossRef]

15. Spudeit, D.A.; Dolzan, M.D.; Breitbach, Z.S.; Barber, W.E.; Micke, G.A.; Armstrong, D.W. Superficially porous particles vs. fully porous particles for bonding high performance liquid chromatographic chiral stationary phases: Isopropyl cyclofructan $6 . J$. Chromatogr. A 2014, 1363, 89-95. [CrossRef]

16. Busse, D.; Templin, S.; Mikus, G.; Schwab, M.; Hofmann, U.; Eichelbaum, M.; Kivistö, K.T. Cardiovascular effects of (R)—and (S)-verapamil and racemic verapamil in humans: A placebo-controlled study. Eur. J. Clin. Pharmcol. 2006, 62, 613-619. [CrossRef]

17. Pagel, P.S.; Hettrick, D.A.; Lowe, D.; Gowrie, P.W.; Kersten, J.R.; Bosnjak, Z.J.; Warltier, D.C. Cardiovascular effects of verapamil enantiomer combinations in conscious dogs. Eur. J. Pharmacol. 1998, 348, 213-221. [CrossRef]

18. Echizen, H.; Manz, M.; Eichelbaum, M. Electrophysiologic effects of dextro-and levo-verapamil on sinus node and AV node function in humans. J. Cardiovasc. Pharmacol. 1988, 12, 543-546. [CrossRef]

19. Bhatti, M.M.; Foste, R.T. Pharmacokinetics of the enantiomers of verapamil after intravenous and oral administration of racemic verapamil in a rat model. Biopharm. Drug Dispos. 1997, 18, 387-396. [CrossRef]

20. Regenthal, R.; Krueger, M.; Koeppel, C.; Preiss, R. Drug levels: Therapeutic and toxic serum/plasma concentrations of common drugs. J. Clin. Monit. Comput. 1999, 15, 529-544. [CrossRef]

21. Eisenberg, J.N.; Oakley, G.D. Probable adverse interaction between oral metoprolol and verapamil. Postgrad. Med. J. 1984, 60, 705-796. [CrossRef] [PubMed]

22. Shen, Z.; Lv, C.; Zeng, S. Significance and challenges of stereoselectivity assessing methods in drug metabolism. J. Pharm. Anal. 2016, 6, 1-10. [CrossRef] [PubMed]

23. Ho, P.C.; Saville, D.J.; Wanwimolruk, S. Simultaneous HPLC analysis of S-and R- verapamil and metabolites, S-and Rnorverapamil in human plasma. J. Liq. Chrom. Rel. Technol. 2000, 23, 1711-1723. [CrossRef]

24. Asafu-Adjaye, E.B.; Shiu, G.K. Solid-phase extraction-high-perfomance liquid chromatography determination of verapamil and norverapamil enantiomers in urine. J. Chromatogr. B 1998, 707, 161-167. [CrossRef]

25. Hanada, K.; Akimoto, S.; Mitsui, K.; Hashiguchi, M.; Ogata, H. Quantitative determination of disopyramide, verapamil and flecainide enantiomers in rat plasma and tissues by high performance liquid chromatography. J. Chromatogr. B 1998, 710, 129-135. [CrossRef]

26. Fieger, H.; Blaschke, G. Direct determination of the enantiomeric ratio of verapamil, its major metabolite norverapamil and gallopamil in plasma by chiral high-performance liquid chromatography. J. Chromatogr. Biomed. Appl. 1992, 572, 255-260. [CrossRef]

27. Shibukawa, A.; Wainer, I.W. Simultaneous direct determination of the enantiomers of verapamil and norverapamil in plasma using a derivatized amylose high-performance liquid chromatographic chiral stationary phase. J. Chromatogr. Biomed. Appl. 1992, 574, 85-92. [CrossRef]

28. Miller, L.; Bergeron, R. Analytical and preparative resolution of enantiomers of verapamil and norverapamil using a cellulosebased chiral stationary phase in the reversed-phase mode. J. Chromatogr. 1993, 648, 381-388. [CrossRef]

29. Berthod, A.; Jin, H.L.; Beesley, T.E.; Duncan, J.; Armstrongs, D.W. Cyclodextrin chiral stationary phases for liquid chromatographic separations of drug stereoisomers. J. Pharm. Biomed. Anal. 1990, 8, 123-130. [CrossRef]

30. Brandsteterova, E.; Wainer, I.W. A chiral and chiral high-performance liquid chromatography of verapamil and its metabolites in serum samples. J. Chromatogr. 1999, 732, 395-404. [CrossRef]

31. Stagni, G.; Gillespie, W.R. Simultaneous analysis of verapamil and norverapamil enantiomers in human plasma by high performance liquid chromatography. J. Chromatogr. B 1995, 667, 349-354. [CrossRef]

32. Rasymasi, A.K.; Botjdoulas, H.; Kichan, J.M. Determination of verapamil enantiomers in serum following racemate administration using HPLC. J. Liq. Chromatogr. Rel.Tech. 1992, 15, 3013-3029. [CrossRef] 
33. Chu, Y.; Wainer, I.W. Determination of the enantiomers of verapamil and norverapamil in serum using coupled achiral-chiral high-performance liquid chromatography. J. Chromatogr. Biomed. Appl. 1989, 497, 191-200. [CrossRef]

34. Sandstrom, R.; Lennernas, H.; Ohlen, K.; Karlsson, A. Enantiomeric separation of verapamil and norverapamil using Chiral-AGP as the stationary phase. J. Pharm. Biomed. Anal. 1999, 2, 43-49. [CrossRef]

35. Lankford, S.M.; Bai, S.A. Determination of the stereochemical composition of the major metabolites of verapamil in doge urine with enantioselective liquid chromatographic techniques. J. Chromatogr. B 1995, 663, 91-101. [CrossRef]

36. Oda, Y.; Asakawa, N.; Kajima, T.; Yoshida, Y.; Sato, T. On-line determination and resolution of verapamil enantiomers by high-performance liquid chromatography with column switching. J. Chromatogr. 1991, 541, 411-418. [CrossRef]

37. Hamidia, S.; Jouyban, A. Capillary electrophoresis with UV detection, on-line stacking and off-line dispersive liquid-liquid microextraction for determination of verapamil enantiomers in plasma. Anal. Methods 2015, 7, 5820-5829. [CrossRef]

38. Resztak, M.; Glowka, F.K. Stereoselective CZE method for analysis of verapamil and norverapamil in human plasma. Acta Pol. Pharm. 2013, 70, 395-401. [PubMed]

39. Dethy, J.M.; Broux, S.D.; Lesne, M.; Longstreth, J.; Gilbert, P. Stereoselective determination of verapamil and norverapamil by capillary electrophoresis. J. Chromatogr. B 1994, 654, 121-127. [CrossRef]

40. Ohara, T.; Shibukawa, A.; Nakagawa, T. Capillary electrophoresis/frontal analysis for microanalysis of enantioseiective protein binding of a basic drug. Anal. Chem. 1995, 67, 3520-3525. [CrossRef]

41. Chankvetadze, B.; Burjanadze, N.; Pintore, G.; Strickmann, D.; Bergenthal, D.; Blaschke, G. Chiral recognition of verapamil by cyclodextrins studied with capillary electrophoresis, NMR spectroscopy, and electrospray ionization mass spectrometry. Chirality 1999, 11, 635-644. [CrossRef]

42. Stalcup, A.M.; Gahm, K.H. Application of sulfated cyclodextrins to chiral separations by capillary zone electrophoresis. Anal. Chem. 1996, 68, 1360-1368. [CrossRef] [PubMed]

43. Clothier, J.G.; Sterling, J.; Tomellini, A. Chiral separation of verapamil and related compounds using micellar electrokinetic capillary chromatography with mixed micelles of bile salt and polyoxyethylene ethers. J. Chromatogr. A 1996, 723, 179-187. [CrossRef]

44. Todoroki, K.; Kudoh, Y.; Nakamura, M.; Shimizu, Y.; Sasaki, T.; Otsuki, H.; Wada, K.; Min, J.Z.; Mizuno, H.; Yoshinari, K.; et al Sensitive and comprehensive LC-MS/MS analyses of chiral pharmaceuticals and their hepatic metabolites using ovomucoid column. Anal. Sci. 2018, 34, 1011-1015. [CrossRef]

45. Singhal, P.; Yadav, M.; Winter, S.; Guttikar, S.; Patel, D.; Mills, M.; Shrivastav, P.S. Enantiomeric separation of verapamil and its active metabolite, norverapamil, and simultaneous quantification in human plasma by LC-ESI-MS-MS. J. Chromatogr. Sci. 2012, 50, 839-848. [CrossRef]

46. Mateus, F.H.; Lepera, J.S.; Marques, M.P.; Boralli, V.B.; Lanchote, V.L. Simultaneous analysis of the enantiomers of verapamil and norverapamil in rat plasma by liquid chromatography-tandem mass spectrometry. J. Pharm. Biomed. Anal. 2007, 45, 762-768. [CrossRef]

47. Alebic-Kolbah, T.; Zavitsanos, A.P. Chiral bioanalysis by normal phase high-performance liquid chromatography-atmospheric pressure ionization tandem mass spectrometry. J. Chromatogr. A 1997, 759, 65-77. [CrossRef]

48. Hedeland, M.; Fredriksson, E.; Lennernäs, H.; Bondesson, U. Simultaneous quantification of the enantiomers of verapamil and its $\mathrm{N}$-demethylated metabolite in human plasma using liquid chromatography-tandem mass spectrometry. J. Chromatogr. B 2004, 804, 303-311. [CrossRef]

49. Rustichelli, C.; Ferioli, V.; Gamberini, G. Resolution of the enantiomers of verapamil and gallopamil by chiral liquid chromatography-mass spectrometry. Chromatographia 1997, 44, 477-483. [CrossRef]

50. Declerck, S.; Vander Heyden, Y.; Mangelings, D. Enantioseparations of pharmaceuticals with capillary electrochromatography. A review. J. Pharm. Biomed. Anal. 2016, 130, 81-99. [CrossRef]

51. Sandra, P. Resolution-definition and nomenclature. J. High. Resolut. Chromatogr. 1989, 12, 82-86. [CrossRef]

52. Nováková, L.; Vlcková, H. A review of current trends and advances in modern bio-analytical methods: Chromatography and sample preparation. Anal. Chim. Acta 2009, 656, 8-35. [CrossRef]

53. U. S. Food and Drug Administration. Bioanalytical Method Validation. Guidance for Industry; FDA: Silver Spring, MD, USA, 2018.

54. Hu, N.; Xie, S.; Liu, L.; Wang, X.; Pan, X.; Chen, G.; Zhang, L.; Liu, H.; Liu, X.; Liu, X.; et al. Opposite effect of diabetes mellitus induced by streptozotocin on oral and intravenous pharmacokinetics of verapamil in rats. Drug Metab. Dispos. 2011, 39, 419-425. [CrossRef]

55. Robinson, M.A.; Mehvar, R. Enantioselective distribution of verapamil and norverapamil into human and rat erythrocytes: The role of plasma protein binding. Biopharm. Drug. Dispos. 1996, 17, 577-587. [CrossRef]

56. Ramaswamy, M.; Wallace, T.L.; Cossum, P.A.; Wasan, K.M. Species differences in the proportion of plasma lipoprotein lipid carried by high-density lipoproteins influence the distribution of free and liposomal nystatin in human, dog, and rat plasma. Antimicrob. Agents Chemother. 1999, 43, 424-1428. [CrossRef]

57. Zhang, Y.; Huo, M.; Zhou, J.; Xie, S. PKSolver: An add-in program for pharmacokinetic and pharmacodynamic data analysis in Microsoft Excel. Comput. Methods Programs Biomed. 2010, 99, 306-314. [CrossRef] 